\title{
The Perceived Stress of Paramedics and Paramedic Students on Their Stress Coping Behaviors During COVID
}

\author{
Dilek BAYKAL ${ }^{1}$ (iD) Sema KOÇ TÜTÜNC ̈̈² iD
}

${ }^{1}$ İstanbul Atlas Üniversitesi, Sağlık Bilimleri Fakültesi, Hemşirelik Bölümü, İstanbul, Türkiye, dbaykal@ hotmail.com (Corresponding Author/Sorumlu Yazar)

${ }^{2}$ Maltepe Üniversitesi, Meslek Yüksekokulu, Tıbbi Hizmetler ve Teknikler Bölümü, İstanbul, Türkiye sematutuncu@maltepe.edu.tr

\begin{tabular}{|c|c|}
\hline Article Info & ABSTRACT \\
\hline $\begin{array}{l}\text { Article History } \\
\text { Received: } 21.12 .2020 \\
\text { Accepted: } 21.03 .2021 \\
\text { Published: } 25.08 .2021\end{array}$ & $\begin{array}{l}\text { Purpose: In the Covid pandemic, especially paramedics and paramedic students took part in the front stages, and } \\
\text { their vital riskd increased by being exposed to high levels of contamination in this process. The risk they are in } \\
\text { can affect the stress they experience and their behavior of coping with stress. The stress they experience may even } \\
\text { lead to change of profession. The study was conducted to understand the perceived stress and coping behaviors of } \\
\text { paramedic students and paramedics. } \\
\text { Methods: An online survey of participants was conducted between July-December } 2020 \text { (n=390). Data was } \\
\text { collected personal information form, Coping Response Inventory and Perceived Stress Scale were used. } \\
\text { Descriptive statistics were used to statistical analysis. }\end{array}$ \\
\hline $\begin{array}{l}\text { Keywords: } \\
\text { Covid, } \\
\text { Stress, } \\
\text { Paramedic, } \\
\text { Paramedic students, } \\
\text { Coping behaviours. }\end{array}$ & $\begin{array}{l}\text { Findings: It is understood that they did not change their perspective on the profession after COVID. There is } \\
\text { significant difference between the income levels and gender of the participants and the averages of both scales. } \\
\text { There were a low level and significant relationship between the perceived stress and stress coping levels of the } \\
\text { participants. } \\
\text { Conclusions and Recommendations: The findings show that participants who do not intend to quit their } \\
\text { profession generally have high perceived stress and low levels of coping with stress. Determining and } \\
\text { supporting the perceived stress and coping levels of healthcare workers during the COVID period can affect } \\
\text { their motivation to quit and work. }\end{array}$ \\
\hline
\end{tabular}

\section{Covid Sürecinde Paramediklerin ve Paramedik Öğrencilerinin Algıladıkları Stres ve Stresle Baş Etme Davranışları}

\begin{tabular}{|c|c|}
\hline Makale Bilgileri & ÖZ \\
\hline $\begin{array}{l}\text { Makale Geçmişi } \\
\text { Geliş: 21.12.2020 } \\
\text { Kabul: } 21.03 .2021 \\
\text { Yayın: } 25.08 .2021\end{array}$ & $\begin{array}{l}\text { Amaç: COVID pandemisinde özellikle paramedikler ve paramedik adayları ön safhalarda görev aldılar ve bu } \\
\text { süreçte yüksek düzeyde kontaminasyona maruz kalarak hayati riskleri arttı. I̧çinde bulundukları risk yaşadıkları } \\
\text { stresi ve stresle başa çıkma davranışlarını etkileyebilir. Araştırma, paramediklerin ve paramedik adaylarının } \\
\text { algıladıkları stresi ve stresle başa çıkma davranı̧̧larını belirlemek amacıyla yapıllmıştır. } \\
\text { Yöntem: Temmuz-Aralık } 2020 \text { (n=390) tarihleri arasında online anket uyguland. Veri toplamada kişsisel bilgi } \\
\text { formu, Stresle Başa Çıkma Ölçeği ve Algıllanan Stres Ölçeği kullanıldı. İstatiksel analizler için tanımlayıcı } \\
\text { analizler kullanıldı. }\end{array}$ \\
\hline $\begin{array}{l}\text { Anahtar Kelimeler: } \\
\text { Covid, } \\
\text { Stres, } \\
\text { Paramedik, } \\
\text { Paramedik öğrencileri, } \\
\text { Başa çıkma davranışları. }\end{array}$ & $\begin{array}{l}\text { Bulgular: COVID sonrası mesleğe bakış açılarını değiştirmedikleri belirlenmiştir. Katılımcıların gelir düzeyleri } \\
\text { ve cinsiyetleri ile her iki ölç̧eğin ortalamaları arasında önemli fark vardır. Katılımcıların algılanan stres ve stresle } \\
\text { başa çıkma düzeyleri arasında düşük düzeyde ve anlamlı bir ilişki vardır. } \\
\text { Sonuç ve Öneriler: Mesleğini bırakma niyetinde olmayan katılımcıların genel olarak algıllanan stresinin yüksek } \\
\text { ve stresle başa çıma düzeylerinin düşük olduğu saptanmıstır. COVID döneminde sağlık çalışanlarının } \\
\text { algıladıkları stresi ve stresle başa çıma seviyelerini belirlemek ve desteklemek işi bırakma ve çalışma } \\
\text { motivasyonlarını etkileyebilir. }\end{array}$ \\
\hline
\end{tabular}

Atıf/Citation: Baykal, D. \& Koç Tütüncü, S. (2021). Covid sürecinde paramediklerin ve paramedik öğrencilerinin algıladıkları stres ve stresle baş etme davranışları, Genel Sağllk Bilimleri Dergisi, 3(2), 90101.

"This article is licensed under a Creative Commons Attribution-NonCommercial 4.0 International License (CC BY-NC $4.0)^{\prime}$ 


\section{INTRODUCTION}

The epidemic caused by the SARS-CoV-2 virus which was first observed in Wuhan, China on 31 December 2019 has spread rapidly to 6 continents and hundreds of countries. This epidemic was recorded in the world's history as the first pandemic to be caused by coronaviruses. The effect of this pandemic which started with the diagnosis of the first case on 11 March 2020 has continued with an increasing effect (Dikmen, et al.,2020). As of October 2020, the total number of cases worldwide has exceeded 36 million. Besides this, more than 1 million deaths have been reported worldwide. Most of these deaths are reported from the USA (55\%) and Europe (23\%) (WHO, 2020). In Turkey, however, the number of cases reported is 379.775, and 10.402 of them resulted in death (WHO/Europe, 2020). When the size and speed of the pandemic and the number of infected and dead individuals are considered, the coronavirus pandemic has caused a huge trauma for people. All life habits of individuals have changed unexpectedly at a social level, and great losses were given (Aykut \& Aykut, 2020). The governments facing this traumatic situation have taken extraordinary measures to limit viral transmission. As a result of these measures, there have been some limitations in the lives and social relationships of individuals. However, healthcare professionals continued to work uninterruptedly with the increasing workload (Babore, et al., 2020).

Healthcare professionals were similarly exposed to various contagious diseases such as HIV, Hep B, Hep C, influenza, and tuberculosis in the past (Thomas, et al., 2017). In 2003, about 850 healthcare professionals were infected with the severe acute respiratory syndrome (SARS) worldwide (Bielajs, et al., 2008). Again, during past epidemics (SARS and MERS), it was observed that healthcare workers have high-stress levels and high-stress levels lead to situations such as anxiety and depression (Babore et al., 2020). It is known that pandemics cause traumatic impacts and increase the anxiety and stress levels of individuals. Pandemics not only affects the patients, but they also affect the individuals who are at risk of pandemics. The anxieties of losing their job, freedom, or not being able to continue their routine life can negatively affect the psychologies of individuals and might turn into behavioral disorders (Aslan \& Sayek, 2020).

Despite the pandemic, healthcare professionals such as doctors, nurses, pharmacists, and paramedics work continuously under stress to increase the well-being of people and slow down the epidemic (Aykut \& Aykut, 2020). And since they are in the front line of the pandemic, they are at a higher risk of infectious diseases. Moreover, they feel stressed with the fear that they might infect their coworkers and families (Elhadi, et al., 2020). Also, they stay away from their loved ones with the possibility that they might be a carrier and therefore staying in quarantine (Aykut \& Aykut, 2020). For these reasons, healthcare professionals are among the professions most affected by the epidemic, which is still not fully controlled and has not yet been treated.

In every country affected by the pandemic, healthcare professionals might have to choose between giving services and protecting themselves. Vital risks and changing challenges about their duties can cause ethical dilemmas (Smith, et al., 2019). Paramedics who first come into contact with the person suspected of Covid cannot be expected to accept life-threatening events while dealing with their patients. However, at some point, the need to be protected from the risks can be more severe than the obligation of care for the patients (Anderson, et al., 2020). Besides, factors such as the fact that the healthcare professionals are at risk of contamination, their intensive working hours, the lack of treatment of the pandemic, and the increasing number of cases can increase stress levels (Elhadi, et al., 2020).

Stress was first defined by Hans Selye in the 1930s. "Stress is an attempt to adapt to a changing situation, with a response that affects our mind, body, nervous system, circulatory system, immune system and many other organs."(Selye, 1975). However, when adaptation is failed, the threat 
perception of the individual changes, and a "stress response" occurs. The stress response is defined as the individual's focus on protecting his balance and himself (Urganc1, 2018). Although individuals are exposed to many different stressors in daily life, stress caused by professional life affects the organism more. An individual might experience work stress while carrying out the roles and responsibilities required by his work or because of the specific risk of the job itself or the intensity of the job (Russel, et al., 2018). Stress in professional life can cause the personnel to carry out his/her normal functions; and therefore, lead to physical and emotional reactions. The reasons such as excessive workload at work, physical and environmental conditions, the presence of a risk factor can cause stress (Kizıl, 2016). High work stress levels, however, can cause negative impacts on the employee (Bakker\&Demerouti, 2018). In order to reduce work stress, individuals need to develop strategies for coping with stress. Although there are many different coping strategies indicated in the literature, the coping strategies developed by de Moos emphasize focusing, and the individual's orientation to the problem. The individual needs to activate cognitive and behavioral coping strategies to reduce stress (Moos,1993). Especially when healthcare professionals cannot develop strategies for coping with stress, this causes them to experience heavy workload, change their professions, or quit their jobs (Duschek, et al., 2020). The perceived stress levels are quite important in the creation of stress response (Russel, et al., 2018). Each person can show different reactions when they are stressed. Responses to stressful situations are influenced by how individuals evaluate potential stressors and the methods they use to cope with these stressful events (Bilge\&Bilge, 2020). The methods used to cope with stress affect the given response. Especially behaviors during a pandemic play an important role in the transmission speed of the pandemic and the number of causalities. For this reason, knowing the psychology and behaviors during a pandemic and managing them successfully is a priority for an effective fight against the pandemic (Aslan, 2020; Korkmaz, et al., 2020). So, it is significant to identify the stress and coping behaviors that may cause healthcare professionals to make mistakes or leave the profession. Therefore, this study is conducted with the aim to evaluate the impact of stress experienced by the paramedics and paramedic candidates on their stress-coping behaviors during COVID-19. It is thought that the findings of this study will help the evaluation of the stress experienced by paramedics and paramedic candidates and their coping behaviors during the COVID pandemic.

\section{METHOD}

\section{Research Design}

The research is planned in a methodological, descriptional study. This study is conducted to evaluate the impact of stress experienced by the paramedics and paramedic candidates on their stresscoping behaviors during COVID-19.

\section{Research Sample}

Study procedures were approved by the institutional review board. Participants were recruited from students studying at the paramedics departments of two foundation universities and voluntary paramedics working for 112 or private ambulance firms. The magic number 384 used in calculations with unclear population is the sufficient sample size regardless of sample size (Barlett, et al., 2001). Based on this information, it was aimed to reach 385 people. Informed consent was obtained from all participants. Since it is not possible to meet in person during a pandemic, the questionaries for the paramedic students and paramedics are made through online survey. 


\section{Participants}

The universe of the study is the paramedic students from two foundation universities and paramedics working for 112 and private ambulances. The study sample includes the students and paramedics who are volunteered for the study. Random sampling is used as the sampling method of the study. In the study, in which a total of 390 usable questionnaires were obtained, the data were collected between July and December 2020.

\section{Research Instruments and Processes}

Information form including participants' personal information, "Perceived Stress Form" to evaluate the perceived stress levels by the participants, and "Coping Response Inventory" to identify stress coping behaviors were used as data collection tools.

Personal Information Form: This form is designed to determine the socio-demographic characteristics (age, marital status, education, income etc.) and perspectives of the participants on their profession.

Perceived Stress Scale: The adaptation of the scale developed by Cohen, Kamarck, and Melmestein to the Turkish community were made by Eskin et al. 2013, and its Cronbach alpha score was calculated as 0.84 (Eskin, et.al., 2013; Cohen, et al., 1983).

The scale consists of 14 questions to evaluate the stress level in the last month. It takes a value between $0-4$ in the 5-point Likert type scale. Options in scale are never, rarely, sometimes, often, and very often. It has two subscales which are insufficient self-efficacy, and perceived stress/distress. The total points that can be scored in this scale change between $0-56$, and the increasing score shows the increase in the perceived stress level. In the total scale score, $0-13$ points are considered low level, 1427 medium level 28-41 high level, and 42-56 very high-level stress.

Coping Response Inventory Scale: Coping response inventory was delivered by Moos (1993) and adopted into the Turkish community by Ballı and Kılıç. The reliability coefficient of the inventory was calculated as 0.93 . The Cronbach Alpha reliability coefficient for the problem-solving sub-scale was $0.91 ; 0.91$ for the positive reappraisal subscale; 0.91 for the logical analysis subscale; 0.80 for seeking professional support subscale; and 0.73 for the environment support subscale (Moos, 1993; Ballı\&Kılıç, 2016).

Participants gave the items in the inventory "5" if they always agree, "4" if they mostly agree, "3" if they sometimes agree, "2" if they rarely agree, "1" if they never agree. As a result of this scoring, while the maximum score to be obtained from an item is 5 , the minimum score I 1 . If the average score obtained from the inventory approaches 5 , it shows that individuals have a high level of coping with stress. The inventory includes a total of 24 items.

\section{Data Analysis}

The data obtained from the research were evaluated via SPSS. The distribution of the data was analyzed before deciding on the type of analysis. The Kolmogorov-Smirnov test was used for normality distribution. Number, \%, mean, and standard deviation were used in descriptive statistics in evaluating the data, and the significance level was accepted as $\mathrm{p}<.05$. T-test was used to compare two independent groups, and one-way analysis of variance (ANOVA) was used in more than two groups.

\section{Ethic}

Approval was obtained from Maltepe University Ethics Committee (07.10.2020/2020/08-09). And also approval was obtained Ministry of Health Scientific Research Platform (2020-0529T19_24_17). This study adheres to the Declaration of Helsinki. Permissions from the ethical board 
are taken before the collection of the data. The participants were informed about the subject, content, and voluntary participation in the questionary before the collection of the data. Permissions are taken from the participants before the application. While applying the questionnaires to the participants included in the sample group, the voluntary principle was taken as a basis. The names of the participants and information about the institutions are not shared in terms of the protection of the confidentiality of personal data.

\section{RESULTS}

The average age of the participants is $22.60 \pm 3.90$, and $66.7 \%$ of them are female. 351 of the participants are single, and $57.9 \%$ of them are students from the paramedics department. And also $68.5 \%$ of the participants have an associate degree, and $68.7 \%$ of them have a moderate income. It is seen that $49.5 \%$ of the participants' perception of their profession has not changed after COVID-19, and $50.5 \%$ of them viewed their profession more positively. In addition, it is understood that only $19.7 \%$ percent of the participants think about changing their profession and/or the department they study after COVID-19 (Table 1).

Table 1. The Descriptive Characteristics of the Participants ( $n=390)$

\begin{tabular}{lcc}
\hline Characteristics & $\mathbf{n}$ & \% \\
\hline Age $(\bar{x}:$ 22.6; Min-Max:18-41) & 220 & 56.4 \\
$\leq 21$ & 170 & 43.6 \\
$\geq 22$ & & \\
Gender & 260 & 66.7 \\
Female & 130 & 33.3 \\
Male & 39 & \\
Marital status & 351 & 10.0 \\
Married & & 90.0 \\
Single & 226 & 57.9 \\
Profession & 164 & 42.1 \\
Paramedic student & & \\
Paramedics & 95 & 24.4 \\
Education & 267 & 68.5 \\
High school & 28 & 7.1 \\
University (2 years) & & \\
University (4 years and $\uparrow)$ & & 18.7 \\
Income & 73 & 68.7 \\
Good & 268 & 12.6 \\
Medium & 49 & \\
Low & & 49.5 \\
Has the participants' view of the profession changed after Covid-19? & 193 & 50.5 \\
Has not changed & 197 & 0 \\
More positively & 0 & 19.7 \\
More negatively & 77 & 80.3 \\
Desire to change profession/department after Covid-19 & 313 & \\
Yes & & \\
No & & \\
\hline
\end{tabular}

The perceived stress scale average scores of the participants are $45.6 \pm 6.6$, the insufficient selfefficacy subscale average is $23.2 \pm 3$.6, and the perceived stress/distress subscale average is $22.8 \pm 3.4$. When it is considered that 0 is the minimum and 56 is the maximum score that can be taken from the general perceived stress scale, is it possible to say that the participants perceived a high level of stress about COVID-19. On the other hand, the total average score of the stress coping inventory is $3.6 \pm 0.5$. And the total average scores of the subscales of the inventory are $3.6 \pm 0.6$ for the problem-solving 
subscale, $3.8 \pm 0.6$ for positive reappraisal, $3.7 \pm 0.6$ for logical analysis, $2.8 \pm 0.8$ for seeking professional support, and 3.9 \pm 0.7 for the environment support subscale (Table 2).

Table 2. The Total Mean Scores and Subscale Scores of the Participants' Perceived Stress Scale and Coping Response Inventory

\begin{tabular}{lccc}
\hline & $\mathbf{M} \pm$ SD & Min-Max & Cronbach Alpha \\
\hline Perceived Stress Scale & $45.6 \pm 6.6$ & $0-56$ & $\mathbf{0 . 8 3}$ \\
Insufficient self-efficacy & $23.2 \pm 3.6$ & $0-28$ & 0.80 \\
Perceived stress/distress & $22.8 \pm 3.4$ & $0-28$ & 0.80 \\
Coping Response Inventory & $3.6 \pm 0.5$ & $1-120$ & $\mathbf{0 . 8 7}$ \\
Problem solving subscale & $3.6 \pm 0.6$ & $1-24$ & 0.64 \\
& & & 0.67 \\
Positive reappraisal subscale & $3.8 \pm 0.6$ & $1-24$ & 0.64 \\
Logical analysis subscale & $3.7 \pm 0.6$ & $1-30$ & 0.58 \\
Seeking professional support subscale & $2.8 \pm 0.8$ & $1-24$ & 0.59 \\
Environment support subscale & $3.9 \pm 0.7$ & $1-24$ & \\
\hline
\end{tabular}

No significant difference was found between the variables of age, marital status, and profession and perceived stress scale, and between the variables of age, gender, marital status, profession, perception about profession after COVID-19, and the intention to change the profession/department of study after COVID-19 and coping stress inventory ( $p>0.05$ ). On the other hand, the scores of the female participants from the perceived stress scale were found to be significantly different than the male participants and participants whose perception about profession did not change after COVID-19 $(\mathrm{p}<0.05)$. Again, it is also determined that the perceived stress scores of the participants who consider changing their profession/ department of study after COVID-19 showed a significant difference $(p<0.05)$. It was found that there is no significant difference between the participants' educational status and the averages of both the perceived stress scale and coping response inventory. However, a statistically significant difference was determined between the income level of the participants and averages of both perceived stress scale and coping stress inventory $(\mathrm{p}<0.05)$. According to the Turkey post-hoc test, it was concluded that the significant difference in terms of perceived stress scale originated from individuals with a perception of poor, moderate, and good income levels $(c>b>a)$. However, in terms of the coping stress scale, it was understood that the significant difference results from the individuals with the perception of good, moderate, and bad levels of income $(a>b>c)$ (Table $3)$.

Table 3. The Comparison of the Participants' Descriptive Characteristics and Their Scores from the Perceived Stress Scale and Coping Stress Inventory

\begin{tabular}{|c|c|c|c|c|}
\hline \multirow{2}{*}{ Characteristics } & \multicolumn{2}{|c|}{ Perceived Stress Scale } & \multicolumn{2}{|c|}{ Coping Response Inventory } \\
\hline & $\mathbf{M} \pm \mathbf{S D}$ & p & $\mathbf{M} \pm \mathbf{S D}$ & p \\
\hline $\begin{array}{l}\text { Age } \\
\leq 21 \\
\geq 22\end{array}$ & $\begin{array}{l}45.7 \pm 6.7 \\
45.4 \pm 6.4\end{array}$ & $0.707 *$ & $\begin{array}{l}3.5 \pm 0.4 \\
3.6 \pm 0.5\end{array}$ & $0.155^{*}$ \\
\hline $\begin{array}{l}\text { Gender } \\
\text { Female } \\
\text { Male }\end{array}$ & $\begin{array}{l}46.5 \pm 6.6 \\
43.8 \pm 6.1\end{array}$ & $0.000 *$ & $\begin{array}{l}3.6 \pm 0.4 \\
3.6 \pm 0.5\end{array}$ & $0.396^{*}$ \\
\hline $\begin{array}{l}\text { Marital status } \\
\text { Married } \\
\text { Single }\end{array}$ & $\begin{array}{l}44.4 \pm 6.6 \\
45.7 \pm 6.5\end{array}$ & $0.253^{*}$ & $\begin{array}{l}3.7 \pm 0.4 \\
3.6 \pm 0.4\end{array}$ & $0.089 *$ \\
\hline $\begin{array}{l}\text { Profession } \\
\text { Paramedic students } \\
\text { Paramedics }\end{array}$ & $\begin{array}{l}45.6 \pm 7.0 \\
45.6 \pm 5.9\end{array}$ & $0.945^{*}$ & $\begin{array}{l}3.5 \pm 0.5 \\
3.6 \pm 0.4\end{array}$ & $0.074 *$ \\
\hline
\end{tabular}




\section{Education}

High school

University (2 years)

$46.2 \pm 6.5$

$45.6 \pm 6.5$

$43.5 \pm 7.4$

$43.9 \pm 6.3$

$45.4 \pm 6.3$

$49.2 \pm 6.9$

Medium (b)

Low (c)

Has the participants' view of the profession changed after Covid-19?

Has not changed

More positively

Desire to change profession/department after Covid-19?

Yes

No

$\mathrm{p}<.05, * \mathrm{t}$ test, $* * \mathrm{~F}$ ANOVA test

$47.2 \pm 6.4$

$44.6 \pm 6.3$

$48.7 \pm 6.8$

$44.8 \pm 6.2$
$0.305 * *$

$3.6 \pm 0.5$

$3.6 \pm 0.4$

$3.7 \pm 0.4$

$3.7 \pm 0.4$

$0.000 * * \quad 3.6 \pm 0.4$

c>b $>a \quad 3.4 \pm 0.5$

$0.000 * *$

$\mathrm{a}>\mathrm{b}>\mathrm{c}$

$0.000 *$

$3.6 \pm 0.5$

$3.6 \pm 0.4$

$0.461 *$

$0.000 *$

$3.5 \pm 0.6$

$3.6 \pm 0.4$

It was seen that there is a negative, low level, and significant relationship (r: -.288) between the perceived stress and stress coping levels of the participants. When the relationships between the perceived stress scale and its subscales were analyzed, it was understood that there is a positive, significant, and high level of relationship between the insufficient self-efficacy subscale and the perceived stress/distress subscale. A similar situation exists between the stress-coping scale and its sub-dimensions. It was found that the relationships between the scale and its subscales vary between .609 and .888 , and this relationship is high level, positive, and significant. On the other hand, although there was a negative, low level, and significant relationship between perceived stress/distress, which is one of the subscales of the perceived stress scale, and seeking professional support from the subscales of the coping response inventory, it was observed that there was no statistically significant relationship between the others (Table 4).

Table 4. Correlation of Perceived Stress Scale and Coping Response Inventory

\begin{tabular}{|l|l|l|l|l|l|l|l|l|}
\hline Scale and subscales & $\mathbf{2}$ & $\mathbf{3}$ & $\mathbf{4}$ & $\mathbf{5}$ & $\mathbf{6}$ & $\mathbf{7}$ & $\mathbf{8}$ & $\mathbf{9}$ \\
\hline Perceived Stress Scale total (1) & $.832^{* *}$ & $.771^{* *}$ & $-.288^{* *}$ & $-.281^{* *}$ & $-.156^{* *}$ & $-.207^{* *}$ & $-.355^{* *}$ & $-.283^{* *}$ \\
\hline Insufficient self-efficacy (2) & & $.306^{* *}$ & $-.440^{* *}$ & $-.410^{* *}$ & $-.322^{* *}$ & $-.348^{* *}$ & $-.377^{* *}$ & $-.388^{* *}$ \\
\hline Perceived stress/ distress (3) & & & -.021 & -.038 & .071 & .020 & $-.181^{* * *}$ & -.086 \\
\hline Coping Response Inventory (4) & & & & $.882^{* *}$ & $.870^{* *}$ & $.888^{* *}$ & $.609^{* * *}$ & $.722^{* *}$ \\
\hline Problem solving subscale (5) & & & & & $.693^{* *}$ & $.673^{* *}$ & $.495^{* * *}$ & $.564^{* *}$ \\
\hline Positive reappraisal subscale (6) & & & & & & $.716^{* *}$ & $.375^{* *}$ & $.544^{* *}$ \\
\hline Logical analysis subscale (7) & & & & & & & $.476^{* *}$ & $.624^{* *}$ \\
\hline $\begin{array}{l}\text { Seeking professional support } \\
\text { subscale (8) }\end{array}$ & & & & & & & & $.375^{* *}$ \\
\hline Environment support subscale (9) & & & & & & & & \\
\hline
\end{tabular}

$* * \mathrm{p}<.01$

\section{DISCUSSION}

It is understood with this study that although the paramedics and paramedic students have highstress levels after the COVID pandemic, they do not consider changing their profession and have a more positive perception about their profession. Also, the participants whose perceived stress levels are high have low levels of coping stress.

It is also found that the participants' perceptions about their profession are more positive after the pandemic and they do not consider changing their profession. Nevertheless, the perceived stress 
levels of the individuals who do not consider quitting their jobs are high because of COVID which had not yet been treated. Paramedics are the first healthcare professionals who intervene in the patient in emergencies. In most cases, they are required to intervene with the patient without having protective equipment because of the urgency of the case and other conditions (Lowe, et al., 2015). For this reason, it is normal for paramedics to have some concerns. However, it is understood that the paramedics and paramedic students participating in this study do not consider quitting their profession. However, in studies conducted with nurses during the COVID pandemic, it is reported that the fact that they are at risk due to spending a long time with patients and the fear of catching a deadly virus, which has not yet had a cure, creates the thought of quitting (Irshad, et al., 2020). The reason for the different results of these studies is thought to be due to the cultural and religious thoughts of the societies. 99.2\% of the people living in Turkey define themselves as Muslim (Rebuplic of Turkey, Presidency of Religious Affairs, 2020). Death is considered as destiny by the Islamic perspective. The fact that death is seen as unchangeable destiny constitutes the idea that whatever is done for people will not change the result (Tayeb, et al., 2010). As a result, the fact that paramedics participating in this study do not consider changing their profession might be linked to their religious beliefs. On the other hand, it is known that in undeveloped countries, the risks of healthcare professionals' catching the virus are high because of inadequate protective equipment and therefore they quit their jobs (Menon \& Padhy, 2020). However, in Turkey, not only there have been no shortages in protective equipment since the beginning of the pandemic, but also protective equipment has been sent to other countries (BBC, 2020). Hence, the paramedics who have not had any difficulties in finding protective equipment might not have had stress caused by the transmission of the disease and therefore might not have thought about quitting their jobs. Similarly, in studies conducted with paramedics, a high level of stress in their jobs indicated as a factor increasing the turnover intention (Cho \& Kang, 2020).

It is found in this study that while the stress levels of the participants with low-income levels are high, their stress coping levels are low. It is known that having a low socio-economic status can increase stress levels. Similar results are found also in this study, and these results are connected with the fact that it is easier for individuals with high income to go into self-isolation and provide more comfortable housing solutions (Dopelt, et al., 2019). Individuals with high-income levels may find an easier solution for their existing problems and therefore can experience less stress. However, there are also some studies indicating that this has nothing to do with the income levels (Babore, et al., 2020). In this study conducted in Italy, it is concluded that stress is not related to economic levels, and this attributed this to the work of health workers without economic expectation (Babore, et al., 2020). Without a doubt, paramedics choose their profession with the emotions of helping other people. However, long working hours can cause their family and private life to be interrupted and they give up their jobs (Dopelt, et al., 2019). On the other hand, the inadequate conditions cause the healthcare professionals concern not only about themselves, but also about their loved ones (Huang, et al., 2020). It may be normal to state that the economic situation does not have an effect on stress in healthcare workers in the study conducted in Italy because according to OECD 2019 data, while GDP per capita is 44.218 USD in Italy, it is 28.424 USD in Turkey (OECD, 2019). Because of the differences in income levels between the countries, it is thought that the low economical levels of the healthcare professionals in Turkey can not only prevent them from developing coping strategies but also cause their perceived stress to be higher.

There is no gender-specific preference in paramedics as in other health disciplines. Although the participants in this study are mainly women, it is a profession preferred also by men. In this study, it is found that the perceived stress of the female participants is higher than males. Paramedics witness various situations where individuals feel pain and suffering such as accidents or violence, and they might experience post traumatic disorder (Bigham, et al., 2014). Students also witness similar cases 
during their internships. These experiences can affect paramedics psychologically. In a study conducted in the UK, it is indicated that about $\% 10$ of the paramedics have depression in clinical levels, and $22 \%$ of them have clinical anxieties (Bennet, et al., 2004). However, women and men show different characteristics due to their physiological structure. In studies conducted with medical rescuers, it is stated that the decision-making process of men is emotionally more stable than women (Orsini \& Setlow, 2017). Paramedics can show maladaptive decision-making styles if they have lower emotional status (Mason, et al., 2020). And maladaptive decision-making styles can cause dissatisfaction, burnout, and stress (Portero de la Cruz, et al., 2020; Vagni, et al., 2020). It is thought that the emotional nature of women cause them to behave more emotional than men and experience more stress. Similarly, in a study conducted with medical students, it is found that women perceive more stress than men (Saeed, et al., 2016). In a study conducted in Turkey, it is revealed that anxiety/stress is higher in women than men (K1z1l, 2016).

In this study, it is found that the perceived stress of the participants with low coping levels is high. Stress, especially the stress caused by work, can negatively affect an individual's life. High levels of anxiety and stress affect even the quality of sleep (Xiao, et al., 2020). Apart from work stress, healthcare professionals experience stress also from isolating their families from infectious diseases during pandemics (Wu, et al., 2020). For this reason, the stress levels of paramedics can increase during pandemics. Another factor affecting stress is the individual's stress coping levels. In a study similarly conducted with this one, it is indicated that bad coping strategies are related to stress (Saczuk, et al., 2019).

Self-efficacy is a person's ability to do something, and self-efficacy is related to psychological well-being and a high quality of life. It is also a coping strategy that allows an individual to reevaluate a negative situation positively. Low levels of self-efficacy can lead to ineffective use of coping strategies and therefore increase the stress levels. In particular, due to the conditions imposed by the COVID pandemic, healthcare professionals experience stress and anxiety because of insufficient selfefficacy (Bandura, 1989; Flesia, et al., 2020; Spoorthy et al., 2020).

Appropriate coping strategies should be used to increase self-efficacy. It is known from studies conducted with nurses that getting social and organizational help is important in providing mental well-being and psychological health (Babore et al.,2020; Labrague et al., 2020). Similar to the study results, it is detected that the stress levels of the individuals with insufficient self-efficacy are high, and coping levels of the individuals who do not seek professional support are low.

\section{LIMITATIONS OF THE STUDY}

Since the study is conducted in Istanbul, it is not possible to generalize the findings to the whole country. Also, using online data collection methods due to the pandemic limited to find out the opinions, feelings, and thoughts of the participants. The lack of studies on this subject in Turkey is also another limitation of this study.

\section{CONCLUSIONS}

In this study, it was understood that the participants' perception of the profession did not change, although the perceived stress level increased after COVID-19. It was also found that those with high stress levels have low levels of coping with stress. Additionally, it was understood that stress levels and coping behaviors were affected by some socio-demographic characteristics. Understanding the underlying reasons of paramedic and paramedic students' failure to cope with 
stress can reduce stress levels. The fact that there are few studies on the stress perceived by paramedics during COVID-19 and their coping levels makes it difficult to compare and generalize the findings. There is a need for comprehensive and comparative studies in this research area.

\section{Funding Sources}

No financial support was received in the study.

\section{Conflict of Interests}

The authors declare that are no conflict of interests.

\section{Author Contribution}

Design: D.B.; Data Collection or Processing: D.B., S.K.T.; Analysis or Interpretation: D.B., S.K.T.; Literature Search: D.B., S.K.T.; Writing: D.B.

\section{REFERENCES}

Anderson, C., Pooley, J.A., Mills, B., Anderson. E., Smith, E.C. (2020). Do paramedics have a professional obligation to work during a pandemic? A qualitative exploration of community member expectations. Disaster Medicine and Public Health Preparedness, 14(3):406-412. https://doi.org/10.1017/dmp.2020.212

Aslan, D., Sayek, I. (2020). We need to rethink on medical education for pandemic preparedness: Lessons learnt from COVID-19. Balkan Medical $\quad$ Journal, 178. https://doi.org/10.4274/balkanmedj.galenos.2020.2020.4.002

Aslan, R. (2020). Tarihten günümüze epidemiler, pandemiler ve Covid-19. Ayrıntı Dergisi, 8(85). http://www.dergiayrinti.com/index.php/ayr/article/view/1353/2382

Aykut, S., Aykut, S.S. (2020). Kovid-19 pandemisi ve travma sonrası stres bozukluğu temelinde sosyal hizmetin önemi. Toplumsal Politika Dergisi, 1(1): 56-66. https: //dergipark.org.tr/tr/pub/tpd/issue/54902/764078

Babore, A., Lombardi, L., Viceconti, M.L., Pignataro, S., Marino, V., Crudele, M., Candelori, C., Bramanti, S.M., Trumello, C. (2020). Psychological effects of the COVID-2019 pandemic: Perceived stress and coping strategies among healthcare professionals. Psychiatry Research, 29: 3113366. https://doi.org/10.1016/j.psychres.2020.113366

Bakker, A.B., Demerouti, E. (2018). Multiple levels in job demands-resources theory: Implications for employee well-being and performance. Handbook of well-being. Salt Lake City, UT: DEF Publishers. DOI: nobascholar.com

Ballı, A.İ.K., Kılıç, K.C. (2016). Stresle başa çıkma yöntemleri ölçeğinin Türkçe 'ye uyarlanması: geçerlilik ve güvenirlik çalışması. Çukurova Üniversitesi Sosyal Bilimler Enstitüsü Dergisi, 2(3): 273-286. https://dergipark.org.tr/tr/download/article-file/364522

Bandura, A. (1989). Regulation of cognitive processes through perceived self-efficacy. Dev. Psychol., 25:729735.

Barlett, J.E., Kotrlik, J.W. \& Higgins, C.C. (2001). Organizational research:Determining appropriate sample size in survey research. Information Technology, Learning, and Performance Journal, 19(1), 43-50.

Bennett, P., Williams, Y., Page, N., Hood, K., Woollard, M. (2004). Levels of mental health problems among UK emergency ambulance workers. Emergency Medicine Journal, 21:235-236. http://dx.doi.org/10.1136/emj.2003.005645

Bielajs, I., Burkle, F.M. Jr., Archer, F.L., Smith, E. (2008). Development of prehospital, population-based triage-management protocols for pandemics. Prehosp Disaster Med., 23(5): 420430. https://doi.org/10.1017/s1049023x00006154

Bigham, B.L., Jensen, J.L., Tavares, W., Drennan, I.R., Saleem, H., Dainty, K.N. Munro, G. (2014). Paramedic self-reported exposure to violence in the emergency medical services (EMS) workplace: a mixed-methods cross-sectional survey. Prehospital Emergency Care, 18(4):489-94. https://doi.org/10.3109/10903127.2014.912703.

Bilge, Y., Bilge, Y. (2020). Koronavirüs salgını ve sosyal izolasyonun psikolojik semptomlar üzerindeki 
etkilerinin psikolojik sağlamlık ve stresle baş etme tarzları açısından incelenmesi. Klinik Psikiyatri Dergisi, 23(1):38-51. https://doi.org/10.5505/kpd.2020.66934

Cho, H.Y., Kang, K.A. (2017). The mediating effects of self-efficacy on the relationship between job stress and turnover intention of paramedics in hospitals. The Korean Journal of Emergency Medical Services, 21(3):109-120. https: //doi.org/10.14408/KJEMS.2017.21.3.109

Cohen, S., Kamarck, T., Mermelstein, R. (1983). A global measure of perceived stress. Journal of Health and Social Behavior, (24): 385-396. https://pubmed.ncbi.nlm.nih.gov/6668417/

Coronavirus: 84 tonnes of PPE to arrive from Turkey. https://www.bbc.com/news/av/uk-52340461 Accessed November 2, 2020.

Dikmen, A.U., Kına, M.H., Özkan, S., İlhan, M.N. (2020). COVID-19 epidemiyolojisi: Pandemiden ne öğrendik. Journal of Biotechnology and Strategic Health Research, (4):29-36. https://doi.org/10.34084/bshr.715153

Dopelt, K., Wacht, O., Strugo, R., Miller, R., Kushnir, T. (2019). Factors that affect Israeli paramedics' decision to quit the profession: a mixed methods study. Israel Journal of Health Policy Research, 8(1): 78. https://doi.org/10.1186/s13584-019-0346-0

Duschek, S., Bair, A., Haux, S., Garrido, A., Janka, A. (2020). Stress in paramedics: relationships with coping strategies and personality traits. International Journal of Emergency Services, 9(2): 203-216. https://doi.org/10.1108/IJES-06-2019-0029

Elhadi, M., Msherghi, A., Alkeelani, M., Zorgani A., Zaid A., Alsuyihli A., Buzreg A., Ahmed, H., Elhahi, A., Khaled, A., Boughididah, T., Khel, S., Abdelkabir, M., Gaffaz, R., Bahroun, S., Alhashimi, A., Biala, M., Abulmida, S., Elharb, A., Abukhashem, M, Elgzairi, M, Alghanani, E, Khaled, T., Boushi, E., Saleim, N.B., Mughrabi, H., Alnafati, N., Alwarfalli, M., Elmabrouk, A., Alhaddad, S., Madi, F., Madi, M., Elkhfeefi, F., Ismaeli, M., Faraag, B., Badi, M., Al-Agile, A., Eisay, M., Ahmid, J., Elmabrouk, O., Alshiteewi, F.B., Alameen, H., Bikhayr, H., Aleiyan, T., Almiqlash, B., Subhi, M., Fadel, M., Yahya, H., Alkot, S., Alhadi, A., Abdullah, A., Atewa, A., Almhai, A. (2020). Assessment of healthcare workers' levels of preparedness and awareness regarding COVID-19 infection in low-resource settings. The American Journal of Tropical Medicine and Hygiene, 103(2): 828-833. https://doi.org/10.4269/ajtmh.20-0330

Eskin, M., Harlak, H., Demirkıran, F., Dereboy, Ç. (2013). Algılanan stres ölçeğinin Türkçeye uyarlanması: güvenirlik ve geçerlik analizi. In New/Yeni Symposium Journal, 51(3):132-140. https://www.researchgate.net/publication/235946078_The_adaptation_of_the_Perceived_Stress_Scale_into_ Turkish_A_reliability_and_validity_analysis

Flesia, L., Monaro M., Mazza C., Fietta, V., Colicino, E., Segatto, B., Roma, P. (2020). Predicting perceived stress related to the Covid-19 outbreak through stable psychological traits and machine learning models. $J$. Clin. Med., 9:3350. https://doi.org/10.31234/osf.io/yb2h8.

Gross domestic product. https://data.oecd.org/gdp/gross-domestic-product-gdp.htm Accessed November 2, 2020.

Huang, L., Lin, G., Tang, L., Yu, L., Zhou, Z. (2020). Special attention to nurses' protection during the COVID19 epidemic. Critical Care, 24:120. https://doi.org/10.1186/s13054-020-2841-7

Irshad, M., Khattak, S. A., Hassan, M. M., Majeed, M., Bashir, S. (2020). How perceived threat of Covid- 19 causes turnover intention among Pakistani nurses: A moderation and mediation analysis. International journal of mental health nursing, Aug $10: 10.1111 /$ inm.12775. doi: $\underline{10.1111 / \mathrm{inm} .12775}$

Kızıl, M. (2016). İzmir 112 ambulanslarında çalışan paramedik ve acil tıp teknisyenlerinin anksiyete düzeyleri ve iş stresörleri. Hastane Öncesi Dergisi, 1(1): 43-54. https://dergipark.org.tr/en/download/articlefile/253471

Korkmaz, M.F., Türe, E., Dorum, B.A., Kılıç, Z.B. (2020). The epidemiological and clinical characteristics of 81 children with COVID-19 in a pandemic hospital in Turkey: an observational cohort study. Journal of Korean Medical Science, (35):25. https://doi.org/10.3346/jkms.2020.35.e236

Labrague, L.J., De Los Santos, J.A.A. (2020). COVID- 19 anxiety among front- line nurses:Predictive role of organisational support, personal resilience and social support. Journal of Nursing Management., 28(7):16531661. https://doi.org/10.1111/jonm.13121

Lowe, J.J., Jelden, K.C., Schenarts, P.J., Rupp, L.E., Hawes, K.J., Tysor, B.M., Swansiger, R.G., Schwedhelm, S.S., Smith, P.W., Gibbs, S.G. (2015). Considerations for safe EMS transport of patients infected with Ebola virus. Prehospital Emergency Care. 2015; 19(2): 179-183. https://doi.org/10.3109/10903127.2014.983661.

Mason, R., Roodenburg, J., Williams, B. (2020). What personality types dominate among nurses and paramedics: A scoping review? Australasian Emergency Care., 23(4):281-290. https://doi.org/10.1016/j.auec.2020.06.001 
Menon, V., Padhy, S.K. (2020). Ethical dilemmas faced by health care workers during COVID-19 pandemic: Issues, implications and suggestions. Asian Journal of Psychiatry., 51: 102116. https://doi.org/10.1016/j.ajp.2020.102116

Moos, R. (1993). Coping responses inventory: Professional manual (2nd ed.). New York: PAR Assessment Resources. New York.

Orsini, C.A. \& Setlow, B. (2017). Sex differences in animal models of decision making. Journal of neuroscience research, 95(1-2): 260-269. https://doi.org/10.1002/jnr.23810

Portero de la Cruz, S., Cebrino, J., Herruzo, J., \& Vaquero-Abellán, M. (2020). A multicenter study into burnout, perceived stress, job satisfaction, coping strategies, and general health among emergency department nursing staff. Journal of Clinical Medicine, 9(4): 1007. https://doi.org/10.3390/jcm9041007

Presidency of the Rebuplic of Turkey, Presidency of Religious Affairs. Türkiye'de Dini Hayat Araştırması, 2014. http://dspace.ceid.org.tr/xmlui/bitstream/handle/1/340/ekutuphane3.5.1.2.15.pdf?sequence=1\&isAllowed=y

Russell, H., Maître, B., Watson, D., Fahey, É. (2018). Job stress and working conditions: Ireland in comparative perspective. An analysis of the European Working Conditions Survey(No. 84). Research Series. https://doi.org/10.26504/rs84

Saczuk, K., Lapinska, B., Wilmont, P., Pawlak, L., Lukomska-Szymanska, M. (2019). Relationship between sleep bruxism, perceived stress, and coping strategies. International Journal of Environmental Research and Public Health, (16)17:3193. https://doi.org/10.3390/ijerph16173193

Saeed, A.A., Bahnassy, A.A., Nasser A, Al-Hamdan, Almudhaibery, F.S., Alyahya, A.Z. (2016). Perceived stress and associated factors among medical students. Journal of Family \& Community Medicine, 23(3):166. https://doi.org/10.4103/2230-8229.189132

Selye, H. (1975). Stress and distress. Comprehensive therapy, 1(8): 9

Smith, E., Burkle Jr, F., Gebbie, K., Ford, D., \& Bensimon, C. (2019). A qualitative study of paramedic duty to treat during disaster response. Disaster medicine and public health preparedness, 13(2): 191-196. https://doi.org/10.1017/dmp.2018.15

Spoorthy, M.S., Pratapa, S.K., Mahant, S. (2020). Mental health problems faced by healthcare workers due to the COVID-19 pandemic-A review. Asian Journal of Psychiatry, 51: 102119. https://doi.org/10.1016/j.ajp.2020.102119

Tayeb, M.A., Al-Zamel, E., Fareed, M.M., Abouellail, H.A. (2010). A “good death": perspectives of Muslim patients and health care providers. Annals of Saudi Medicine, 30(3): 215-221. https://doi.org/10.4103/02564947.62836

Thomas, B., O'Meara, P., Spelten, E. (2017). Everyday dangers-the impact infectious disease has on the health of paramedics: a scoping review. Prehospital and Disaster Medicine, 32(2): 217-223. https://doi.org/10.1017/S1049023X16001497

Turkey-Response to Covid-19 Pandemic. https://www.euro.who.int/en/countries/turkey/turkey-response-tocovid-19-pandemic Accessed September 14, 2020.

Urganc1, Ç. (2018). Ístanbul 112 Acil sağlık hizmetleri çalışanlarının mesleki tükenmişlik düzeyleri, algılanan stres düzeyi ve stresle başa çıkma stillerinin evlilik doyumunu yordama gücü (Doctoral Dissertation, İstanbul Aydın Üniversitesi Sosyal Bilimler Enstitüsü) İstanbul.

Vagni, M., Maiorano, T., Giostra, V., \& Pajardi, D. (2020). Coping with COVID-19: emergency stress, secondary trauma and self-efficacy in healthcare and emergency workers in Italy. Frontiers in Psychology, 11:566912. https://doi.org/10.3389/fpsyg.2020.566912

WHO Coronavirus Disease (COVID-19). https://covid19. who.int Accessed September 14, 2020.

Wu, P.E., Styra, R., Gold, W.L. (2020). Mitigating the psychological effects of COVID-19 on health care workers. CMAJ, 192(17): E459-E460. https://doi.org/10.1503/cmaj.200519

Xiao, H., Zhang, Y., Kong, D., Li, S., Yang, N. (2020). Social capital and sleep quality in individuals who selfisolated for 14 days during the coronavirus disease 2019 (COVID-19) outbreak in January 2020 in China. Medical science monitor: international medical journal of experimental and clinical research, 26: e923921-1. https://doi.org/10.12659/MSM.923921 